\title{
Design And Build A Web-Based Asset Management Information System at Pt Thamrin Telekomunikasi Network
}

\author{
Muhammad Yusuf Effendy ${ }^{1}$, Euis Nurninawati ${ }^{2}$, Ahmad Ari Setiyawan ${ }^{3}$ \\ University of Raharja, Indonesia ${ }^{1,2,3}$ \\ e-mail: yusuf.effendy@raharia.info ${ }^{1}, \underline{\text { euis.nurninawati@raharia.info }}^{2}, \underline{\text { ahmad.ari@raharia.info }}^{3}$
}

Effendy, Y., Nurninawati, E. ., \& Setiawan, A. (2022). MANAGEMENT INFORMATION SYSTEM DESIGN WEB-BASED ASSETS AT PT THAMRIN TELECOMMUNICATION NETWORK. Aptisi Transactions on Technopreneurship (ATT), 4(1).

DOI: https://doi.org/10.34306/att.v4i1.233

\begin{abstract}
Asset management is a series of activities related to identifying needed assets, identifying funding needs, acquiring assets, providing logistical support, and maintenance systems for assets, deleting or updating assets in order to achieve effectively and efficiently. At PT Thamrin Telekomunikasi Network, data collection on each company's IT assets, such as laptops, servers, network devices, and other peripheral devices is done manually using Microsoft Excel. However, sometimes IT staff forget to update data such as expiration date of the asset warranty period and transfer of asset ownership, as well as marking on assets still using handwritten stickers manually. Through this research, the author aims to design and implement a web-based IT asset management information system at PT Thamrin Telekomunikasi Network. The methods used in this research are interviews, observation, and literature study. The analytical method used is the PIECES method and the system design that is made is described by the UML (Unified Modeling Language) method, for application development using the SDLC method with the Extreme Programming model, as well as the application testing method, will use Black Box method. The final result from this research is a web-based IT asset management system that is built with HTML and Javascript programming languages, with MariaDB as the DBMS and using Laravel and Bootstrap as a framework of PHP and CSS. It is hoped that with this application, the IT asset management process at PT Thamrin Telekomunikasi Network can run more effectively, organized, and more efficiently.
\end{abstract}

Keywords: Information Systems, Asset Management, Web

\section{Introduction}

Information technology is an important thing that can affect the development of a company, including the application of information technology to the management of assets owned by an institution or company. Asset management is a series of activities related to identifying needed assets, identifying funding needs, acquiring assets, performing asset maintenance, to deleting or updating asset data. 
PT Thamrin Telekomunikasi Network is an industry engaged in IT Managed Services that provides several services such as Colocation Server, Internet Service Provider and Outsource IT, Engineer. This company has quite a lot of IT assets, so to maximize their management, IT staff need an integrated asset management information system to be able to manage IT assets more efficiently, precisely, and accurately. However, at this time, IT asset management is still carried out semi-computerized using Microsoft Excel. This often causes duplication of data or other problems such as data on the warranty period of IT assets and repair status of damaged IT assets that are not updated. In addition, because asset data is still stored in excel format, it is prone to changes or manipulation of data by unauthorized parties, both internal and external to the company.

Based on the above problems, the authors aim to conduct research by designing and building an IT asset management information system at PT Thamrin Telekomunikasi Network. So that it can facilitate IT, staff in maintaining and monitoring or supervising IT assets more effectively and efficiently. So in this study, the author took the title "Rancang Bangun Sistem Informasi Manajemen Aset Berbasis Web pada PT Thamrin Telekomunikasi Network".

\section{Literature Review}

Tabel 1. Literature Review

\begin{tabular}{|c|c|c|c|}
\hline No & Penulis dan Judul & Metode & Hasil Penelitian \\
\hline 1. & 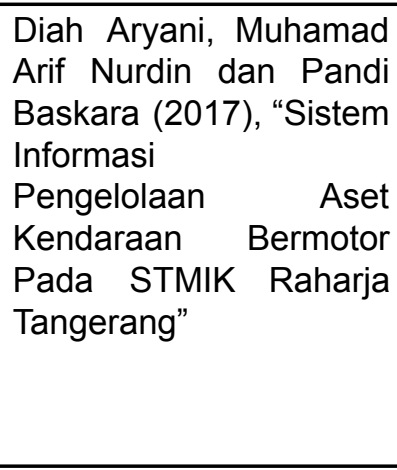 & $\begin{array}{l}\text { The design method uses UML, } \\
\text { the PHP programming language } \\
\text { and the Yii } 2 \text { framework, the } \\
\text { database uses MySQL Server, } \\
\text { and Sublime Text as a text editor } \\
\text { which is used in designing the } \\
\text { motor vehicle asset } \\
\text { management website in } \\
\text { STMIK Raharja. }\end{array}$ & $\begin{array}{l}\text { The final result } \\
\text { achieved is a } \\
\text { web-based motor } \\
\text { vehicle asset } \\
\text { management } \\
\text { application that can } \\
\text { run more efficiently } \\
\text { and effectively } \\
\text { compared to a } \\
\text { system that is still } \\
\text { running manually. }\end{array}$ \\
\hline 2. & $\begin{array}{l}\text { Ardiyan Agus Prayogo, } \\
\text { Sri Handoyo Prapto, } \\
\text { (2020), "Perancangan } \\
\text { Aplikasi Monitoring Data } \\
\text { Aset IT Berbasis Web } \\
\text { pada PT Gratia Prima } \\
\text { Indonesia" }\end{array}$ & $\begin{array}{l}\text { Design method using UML } \\
\text { (Unified Modeling Language), } \\
\text { with Codeigniter framework as } \\
\text { well as MySQL databases. } \\
\text { Using SDLC with the waterfall } \\
\text { method as the application } \\
\text { design stage and Black box } \\
\text { testing as the testing stage. }\end{array}$ & $\begin{array}{l}\text { Results of research } \\
\text { this is a web-based } \\
\text { asset monitoring } \\
\text { application system } \\
\text { that can run more } \\
\text { effectively } \quad \text { and } \\
\text { efficiently. }\end{array}$ \\
\hline 3. & $\begin{array}{l}\text { Sri Hardiyanti, (2018), } \\
\text { "Perancangan Sistem } \\
\text { Informasi Manajemen } \\
\text { Aset Berbasis Web } \\
\text { pada PD BPR Kerta } \\
\text { Raharja } \\
\text { Cabang Balaraja" }\end{array}$ & $\begin{array}{l}\text { Design using UML (Unified } \\
\text { Modeling Language), with } \\
\text { Codeigniter framework as well } \\
\text { as } \\
\text { MySQ databases. Using } \\
\text { SDLC with waterfall method as } \\
\text { the application design stage } \\
\text { and Black box testing as the } \\
\text { testing stage. } \\
\text {. }\end{array}$ & $\begin{array}{l}\text { Results of research } \\
\text { This is in the form of } \\
\text { recommendations } \\
\text { and suggestions for } \\
\text { developing } \\
\text { information systems } \\
\text { in accordance with } \\
\text { user needs as stated } \\
\text { in the information } \\
\text { system } \\
\text { elicitation. }\end{array}$ \\
\hline
\end{tabular}




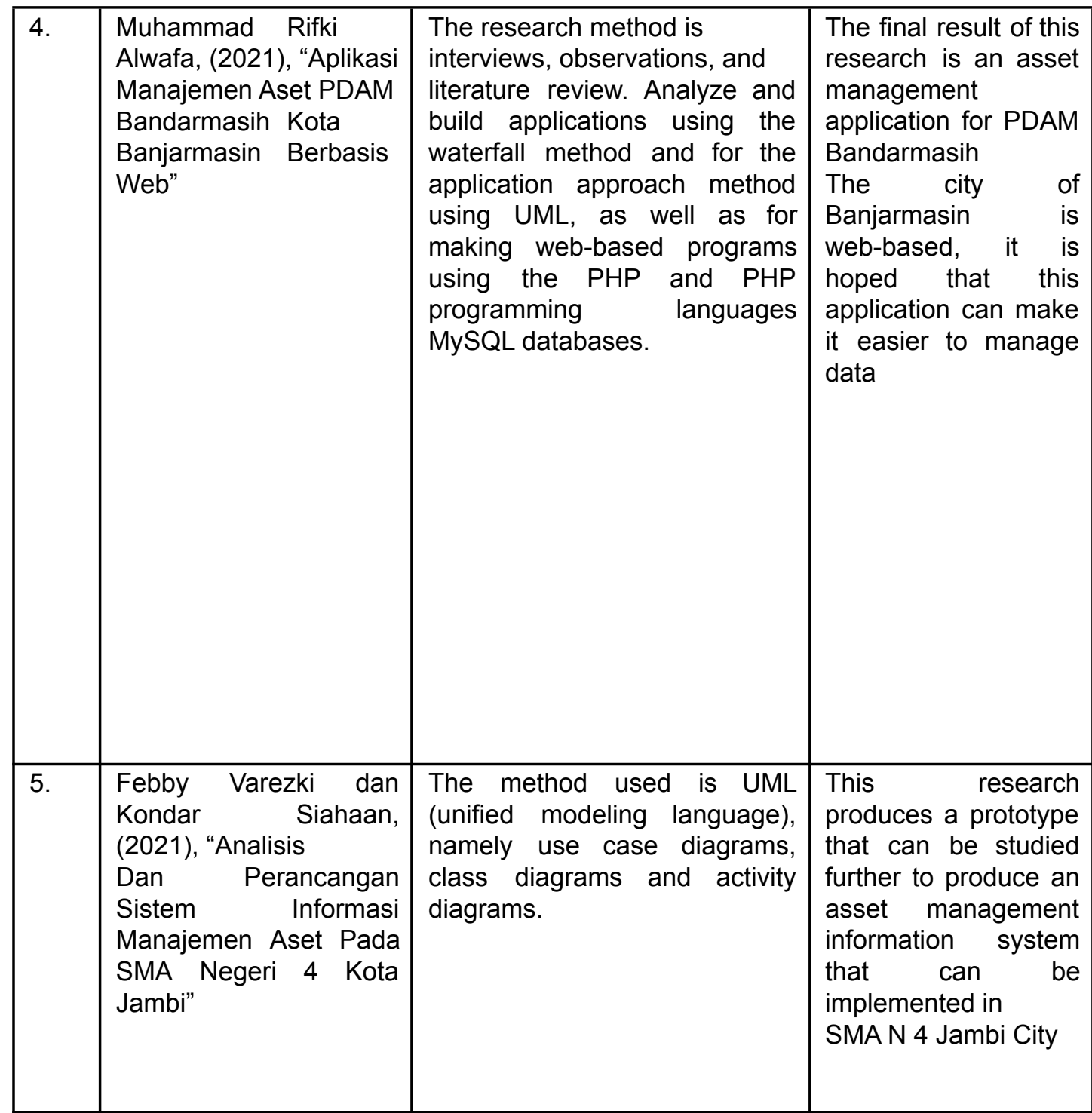

The results of this literature study demonstrate a solid foundation and strong reasons for developing a better information delivery system with careful consideration. The gaps have been identified properly so there is no reinventing the wheel. The review has been carried out carefully, so that it is certain that it will produce maximum final results, be more effective, and make it easier for users to provide information and manage asset data on PT Thamrin Telekomunikasi Network.

\section{Research Method}

In order to produce works that are in accordance with scientific theory and are effective, then in their preparation, there are several methods applied, including

\subsection{Observation}

In this method, researchers make observations to the company PT Thamrin Telekomunikasi Network so that the authors can get the data needed to conduct research

\subsection{Analyze}

Stages of analysis of a system or application is carried out before the design stage is carried out. The purpose of applying analysis to a system is to find out the reasons why the 
system is needed, formulate the needs of the system to reduce excess resources, and help plan the scheduling of system formation, minimizing distortions that may exist in the system so that the functions in the system works optimally. The analytical method used by the researcher here is to use the PIECES method, namely:

A. Performance

Tabel 2. Performance Parameter

\begin{tabular}{|l|l|}
\hline \multicolumn{1}{|c|}{ Parameter } & \multicolumn{1}{c|}{ Result } \\
\hline Throughput & $\begin{array}{l}\text { Performance is less effective because the } \\
\text { process of requesting new assets, collecting } \\
\text { asset data, updating and deleting asset data } \\
\text { until the preparation of asset data reports is still } \\
\text { done manually. }\end{array}$ \\
\hline Response Time & $\begin{array}{l}\text { Response times in asset data collection and } \\
\text { report generation are long because they have to } \\
\text { make comparisons between incoming, outgoing } \\
\text { asset data, and assets that are being repaired. }\end{array}$ \\
\hline
\end{tabular}

B. Information

Tabel 3. Information Parameter

\begin{tabular}{|l|l|}
\hline \multicolumn{1}{|c|}{ Parameter } & \multicolumn{1}{c|}{ Result } \\
\hline Accuracy & $\begin{array}{l}\text { The information presented is still not accurate, } \\
\text { because the data is still stored in several } \\
\text { different excel files. So errors often occur in the } \\
\text { process of delivering data information. }\end{array}$ \\
\hline Punctuality & $\begin{array}{l}\text { Response times in asset data collection and } \\
\text { report generation are long because they have to } \\
\text { make comparisons between incoming, outgoing } \\
\text { asset data, and current assets. } \\
\text { repairs were made. }\end{array}$ \\
\hline Relevant & $\begin{array}{l}\text { The information provided is still less relevant } \\
\text { due to errors that occur in asset data collection } \\
\text { which are often not updated. }\end{array}$ \\
\hline
\end{tabular}

C. Economy

Tabel 4. Economy Parameter

\begin{tabular}{|l|l|}
\hline \multicolumn{1}{|c|}{ Parameter } & \multicolumn{1}{c|}{ Hasil Analisa } \\
\hline Fee & $\begin{array}{l}\text { Performance is less effective because the } \\
\text { process of requesting new assets, and asset } \\
\text { repairs are still done manually using paper } \\
\text { forms, which require additional costs every } \\
\text { month. }\end{array}$ \\
\hline
\end{tabular}


D. Control

Tabel 5. Control Parameter

\begin{tabular}{|l|l|}
\hline \multicolumn{1}{|c|}{ Parameter } & \multicolumn{1}{c|}{ Hasil Analisa } \\
\hline Accessibility & $\begin{array}{l}\text { Data dapat diakses oleh setiap orang selama } \\
\text { mereka mengetahui lokasi file excel atau data } \\
\text { aset IT, sehingga tidak mudah mengontrolnya } \\
\text { karenarawan terjadi perubahan data oleh pihak } \\
\text { yang tidak bertanggung jawab. }\end{array}$ \\
\hline
\end{tabular}

\subsection{Design Method}

The design method in this study uses the SDLC (Software Development Life Cycle) Extreme Programming (Agile) method. Then to provide an overview and design of the system development to be made, the author uses the UML (Unified Modeling Language) model using the Visual Paradigm application which consists of Use Case Diagrams, Activity Diagrams, Sequence Diagrams, and Class Diagrams. In this design, the author also uses the Javascript programming language with the help of the Visual Studio Code application as a code editor. In addition, the author also uses Laravel as a PHP framework and Bootstrap as a CSS framework to support the appearance and performance of the website so that it can be better, attractive, and dynamic. For database design, the author will use MariaDB as the DBMS and Laragon as the webserver which will later be used in the design and development of the proposed application. 


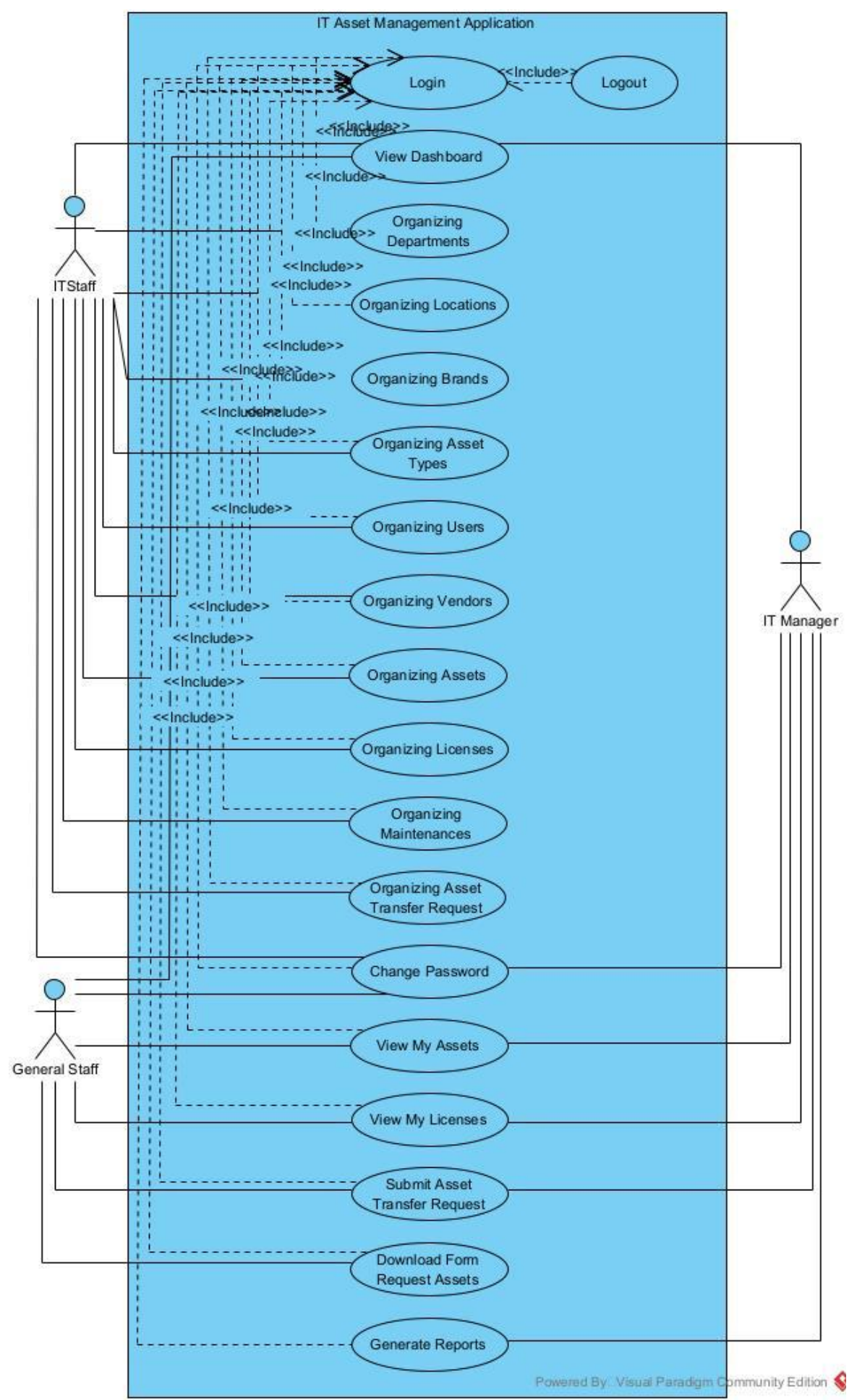

Figure 1. Use Case Diagram of the Proposed System

Based on the Use Case Diagram of the proposed system above, there are

A. 3 actors, namely IT staff, IT manager and non-IT staff

B. 19 use cases carried out by actors, including logging in, viewing dashboards, managing departments, managing locations, managing brands, managing asset types, managing user lists, managing vendor lists, managing assets, managing licenses, managing devices being repaired, manage asset transfer requests, 
change passwords, view a list of assets owned, view a list of licenses owned, submit an asset transfer request, download an asset request form, withdraw a report or log out.

\section{Result and Discussion}

In the research that has been done, at this stage will display the results obtained from the proposed use case diagram that is suitable as a proposal in this study.

\section{A. Procedure Difference Between Current System and Proposed System}

Based on the analysis and design that has been done, there are several differences between the current system and the proposed system. Namely as follows:

Tabel 6. Performance Parameter

\begin{tabular}{|l|l|l|}
\hline No. & \multicolumn{1}{|c|}{ The running system } & \multicolumn{1}{c|}{ Proposed system } \\
\hline 1. & $\begin{array}{l}\text { Using Ms. Excel } \\
\text { to input IT assets }\end{array}$ & $\begin{array}{l}\text { It's fully computerized using a local server } \\
\text { and web-based system }\end{array}$ \\
\hline 2. & $\begin{array}{l}\text { Report processing is still done } \\
\text { manually }\end{array}$ & $\begin{array}{l}\text { Reports can be automatically generated } \\
\text { by the system }\end{array}$ \\
\hline 3. & $\begin{array}{l}\text { The asset monitoring process by IT } \\
\text { managers is carried out by looking } \\
\text { at the master excel data }\end{array}$ & $\begin{array}{l}\text { The monitoring process can be carried out } \\
\text { through a web-based application by adding } \\
\text { the role of IT Manager and given access to } \\
\text { generate report }\end{array}$ \\
\hline 4. & $\begin{array}{l}\text { Labeling of IT assets is still done } \\
\text { by writing assets tag on label }\end{array}$ & $\begin{array}{l}\text { Labels can be generated using a qr code, } \\
\text { then printed and pasted on related IT } \\
\text { assets }\end{array}$ \\
\hline
\end{tabular}

B. Prototype Design

1. Login Page

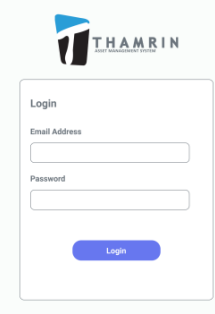

Figure 2. Login Page 
2. Dashboard Page View

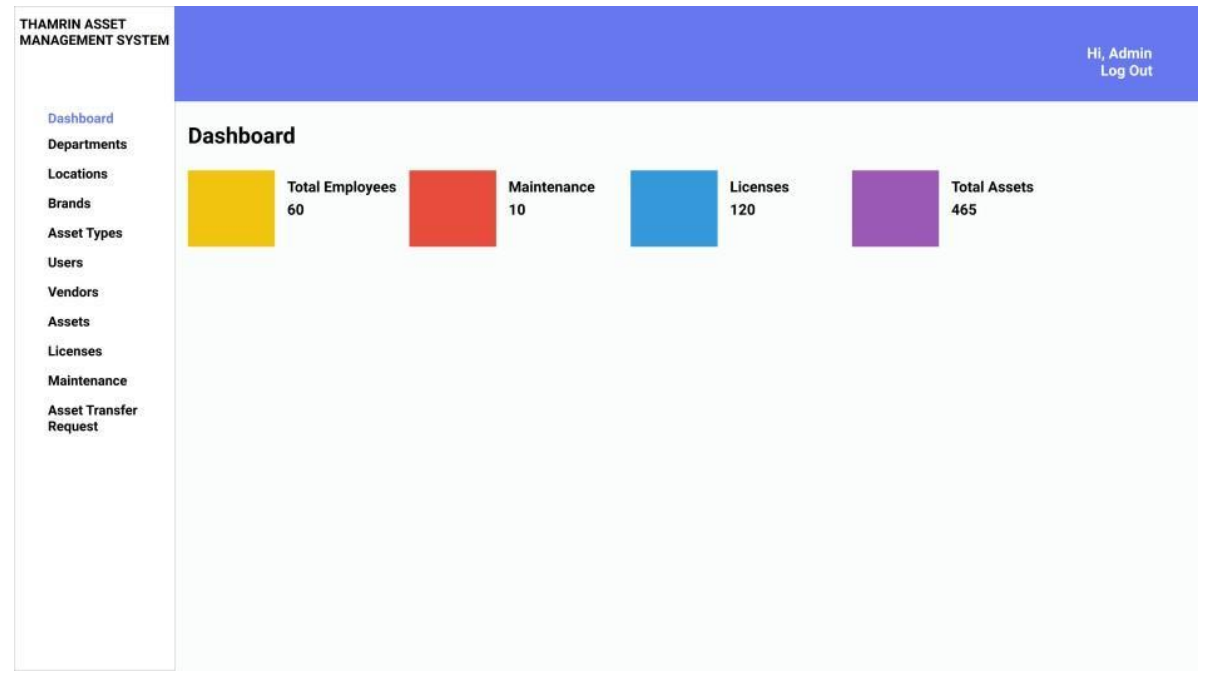

Figure 3. Dashboard Page View

3. Assets Page View

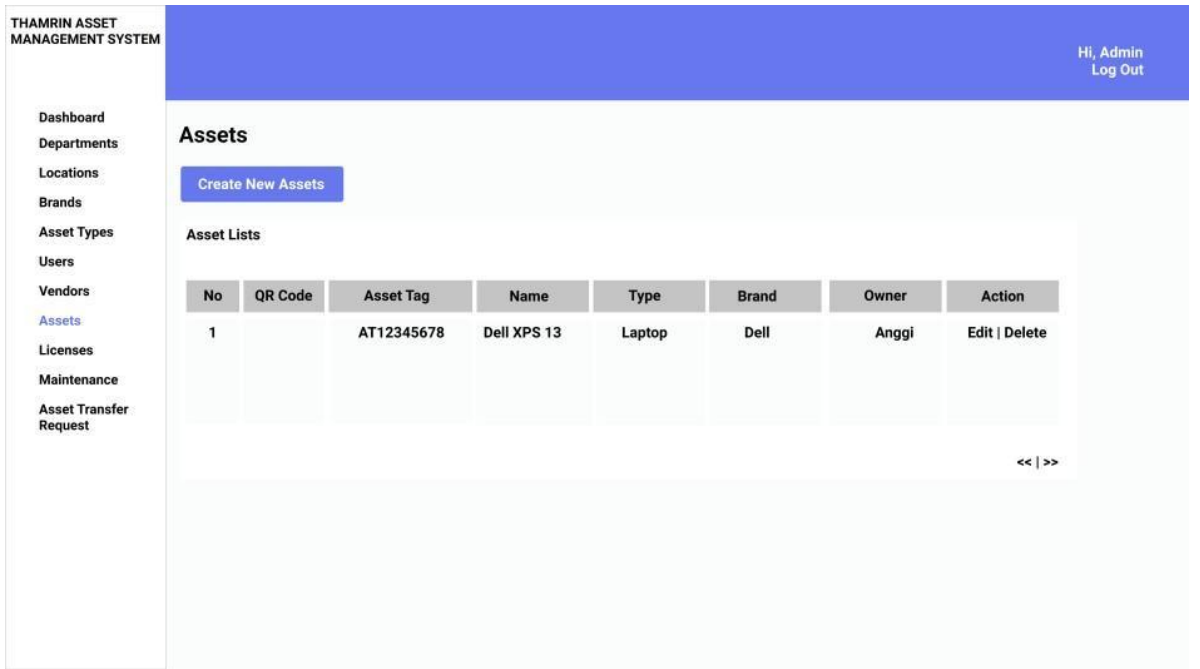

Figure 4. Assets Page View 
4. Add Assets Halaman Page View

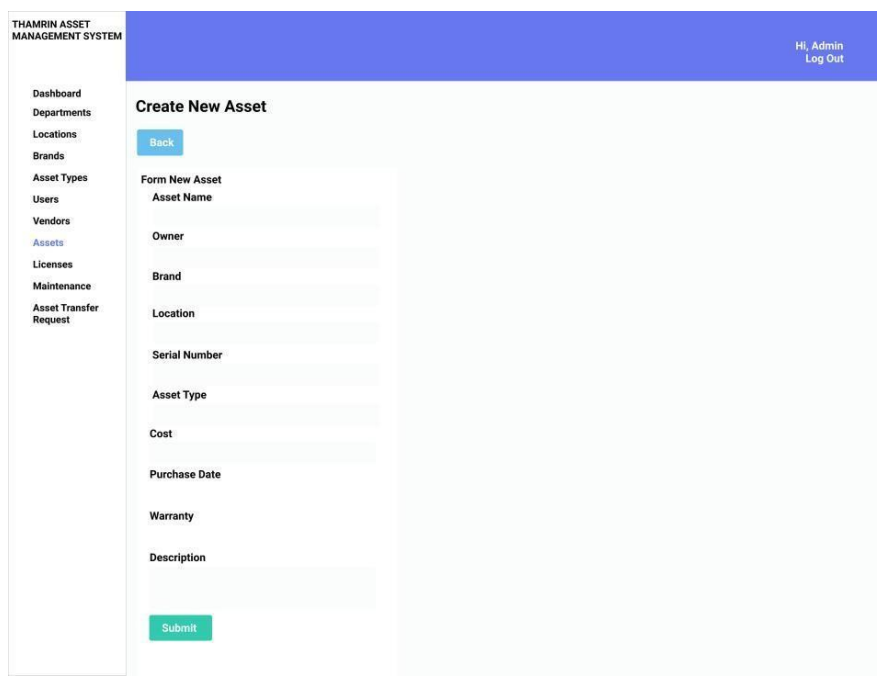

Figure 5. Add Assets Page View

5. Licenses Page View

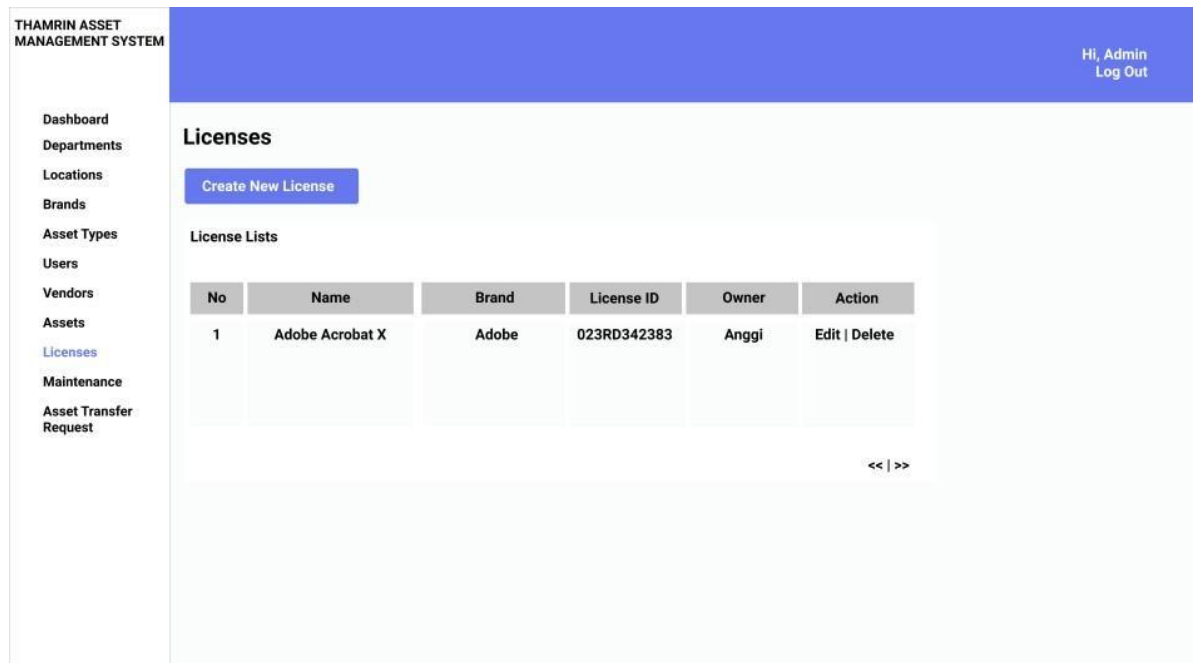

Figure 5. License Page View

\section{Conclusion}

The current IT asset management system at PT Thamrin Telekomunikasi Network is semi-computerized, using excel format. For each new asset that is received, details will be recorded, then the asset tag will be attached using a label on the asset. The same thing happens to damaged assets. Any damaged assets that cannot be repaired will be auctioned off and removed from the excel master data. The obstacle faced by the current system is that the process of submitting and requesting IT asset repair is still done manually using paper forms as the medium, which is less efficient because users and IT staff have to meet the IT Manager and Purchasing directly to seek approval. In addition, 
prone to damage or lost form. The process of managing incoming and outgoing assets is still done using an excel file, so it is prone to happen.

Through the proposed use case diagram, it is easier for IT staff to manage existing assets at PT Thamrin Telekomunikasi Network. So that data can be stored in a database and centralized in an application, and minimize the possibility of duplication, manipulation, and data loss.

\section{References}

[1] Febriyanto, E., Naufal, R. S., \& Sulistiawati, S. (2020). Planning of the Web-based E-Raport Assessment System. Aptisi Transactions On Technopreneurship (ATT), 2(1), 48-58.

[2] Balazinska, M., Deshpande, A., Franklin, M. J., Gibbons, P. B., Gray, J., Hansen, M., ... \& Tao, V. (2007). Data management in the worldwide sensor web. IEEE Pervasive Computing, 6(2), 30-40.

[3] Gonzalez, H., Halevy, A. Y., Jensen, C. S., Langen, A., Madhavan, J., Shapley, R., ... \& Goldberg-Kidon, J. (2010, June). Google fusion tables: web-centered data management and collaboration. In Proceedings of the 2010 ACM SIGMOD International Conference on Management of data (pp. 1061-1066).

[4] Chu, X., \& Fan, Y. (1999). Product data management based on web technology. Integrated Manufacturing Systems.

[5] Deus, H. F., Stanislaus, R., Veiga, D. F., Behrens, C., Wistuba, I. I., Minna, J. D., ... \& Almeida, J. S. (2008). A semantic web management model for integrative biomedical informatics. PloS one, 3(8), e2946.

[6] Fauzan, R., Siahaan, D., Rochimah, S., \& Triandini, E. (2019, July). Use case diagram similarity measurement: A new approach. In 2019 12th International Conference on Information \& Communication Technology and System (ICTS) (pp. 3-7). IEEE.

[7] P. A. Sunarya, U. Rahardja, and D. I. Desrianti, "Development Assessment Module Portfolio E-Imei Students With Learning To Improve The Quality Of Concentration Case Study Mavib," vol. 13, no. 8, pp. 3597-3606, 2016.

[8] Williams, A., \& Dolan, E. (2020). Application of Blockchain Technology in e-LoA Technopreneurship Journal. Aptisi Transactions On Technopreneurship (ATT), 2(1), 98-103.

[9] Arora, K., \& Bist, A. S. (2020). Artificial intelligence based drug discovery techniques for covid-19 detection. Aptisi Transactions On Technopreneurship (ATT), 2(2), 120-126.

[10] T. Hariguna, U. Rahardja, Q. Aini, and Nurfaizah, "Effect of social media activities to determinants public participate intention of e-government," Procedia Comput. Sci., vol. 161, pp. 233-241, 2019, doi: 10.1016/j.procs.2019.11.119.

[11] N. F. Rozy, R. Ramadhiansya, P. A. Sunarya, and U. Rahardja, "Performance Comparison Routing Protocol AODV, DSDV, and AOMDV with Video Streaming In Manet," in 2019 7th International Conference on Cyber and IT Service Management (CITSM), 2019, vol. 7, pp. 1-6.

[12] Yuniva, Ika, and Dany Hestiyanto. 2018. Perancangan Web e-Commerce untuk penjualan sepatu dengan pendekatan model Classic Life Cycle. Tangerang: Journal CERITA Vol.4, No.1, 24-33.

[13] L. Laguna, S. Fiszman, P. Puerta, C. Chaya, and A. Tárrega, "The impact of COVID-19 lockdown on food priorities. Results from a preliminary study using social media and an online survey with Spanish consumers," Food Qual. Prefer., vol. 86, p. 104028, 2020.

[14] S. A. Zope, R. A. Zope, G. A. Biri, and C. S. Zope, "Sudarshan kriya yoga: A breath of hope during covid-19 pandemic," Int. J. Yoga, vol. 14, no. 1, p. 18, 2021.

[15] I. U. Rahardja and S. Raharja, "Artificial informatics," 2009 4th IEEE Conf. Ind. Electron. Appl. ICIEA 2009, pp. 3064-3067, 2009, doi: 10.1109/ICIEA.2009.5138764.

[16] Panjaitan, A. R. S., Rahardja, U., Aini, Q., Santoso, N. P. L., \& Apriliasari, D. (2022). The Management Innovation of Kuliah Kerja Praktek (KKP). APTISI Transactions on Management (ATM), 6(1), 62-73. 
[17] H. Yang et al., "Difficulties and Countermeasures in Hospital Emergency Management for Fast-Lane Treatment of Acute Stroke During the COVID-19 Epidemic Prevention and Control," Front. Neurol., vol. 11, p. 1476, 2020.

[18] Sanni, M. I., \& Apriliasari, D. (2021). Blockchain Technology Application: Authentication System in Digital Education. Aptisi Transactions on Technopreneurship (ATT), 3(2), 37-48.

[19] A. S. Bein, Y. I. Graha, and A. P. Pangestu, "Pandawan Website Design Based Content Management System As Media E-commerce Transaction," Aptisi Trans. Technopreneursh., vol. 2, no. 1, pp. 87-97, 2020.

[20] Vachharajani, V., \& Pareek, J. (2020). Effective Structure Matching Algorithm for Automatic Assessment of Use-Case Diagram. International Journal of Distance Education Technologies (IJDET), 18(4), 31-50. 